\title{
LITERASI KREATIF: MEMBANGUN KETERAMPILAN ABAD 21 MELALUI PEMBELAJARAN SEJARAH LOKAL KESULTANAN LANGKAT
}

\author{
Septiansyah Tanjung ${ }^{\bowtie}$, Nana Supriatna \\ Postgraduate History Education Universitas Pendidikan Indonesia
}

\begin{tabular}{l}
\hline Info Artikel \\
\hline Sejarah Artikel: \\
Disubmit: September \\
2021 \\
Direvisi: Oktober 2021 \\
Diterima: November \\
2021 \\
\hline Keywords: \\
Local History Learning; \\
Creative Pedagogy; Literacy \\
Learning, 21' Century Skill \\
\hline
\end{tabular}

\begin{abstract}
Abstrak
Perkembangan era digital telah memberi banyak perubahan dalam kehidupan manusia termasuk transformasi pendidikan dan literasi. Literasi dan kreativitas menjadi kompetensi penting yang harus dikembangkan kepada peserta didik melalui proses pembelajaran. Pedagogi kreatif menjadi solusi untuk memecahkan persoalan tersebut melalui pembelajaran sejarah lokal Kesultanan Langkat, pendekatan pedagogi kreatif dapat diterapkan dengan memadukan penggunaan literasi untuk melaksanakan pembelajaran. Dengan menggunakan studi literatur, Penulis mengkonstruksi pembahasan mengenai bagaimana menerapkan pedagogi kreatif dan pembelajaran literasi dalam pembelajaran sejarah lokal Kesultanan Langkat. Integrasi dari sejumlah pendekatan tersebut menghasilkan konsep literasi kreatif yang memberikan kesempatan kepada peserta didik untuk mengembangkan multikompetensi seperti keterampilan abad 21 dan keterampilan literasi, termasuk literasi digital.
\end{abstract}

\begin{abstract}
The development of the digital era has brought many changes in human life, including the transformation of education and literacy. Literacy and creativity are important competencies that must be developed for students through the learning process. Creative pedagogy is a solution to solve these problems through learning the local history of the Langkat Sultanate, a creative pedagogical approach can be applied by combining the use of literacy to carry out learning. By using a literature study, the author constructs a discussion on how to apply creative pedagogy and literacy learning in learning the local history of the Langkat Sultanate. The integration of a number of these approaches results in the concept of creative literacy which provides opportunities for students to develop multicompetencies such as 21st century skills and literacy skills, including digital literacy.
\end{abstract}

(C) 2021 Universitas Negeri Semarang

$\begin{array}{lr}{ }^{凶} \text { Alamat korespondensi: } & \text { ISSN 2252-7133 } \\ \text { Universitas Pendidikan Indonesia } & \text { E-ISSN 2548-4648 } \\ \text { E-mail: septiansyahtanjung@upi.edu } & \end{array}$




\section{PENDAHULUAN}

Melimpahnya sumber daya informasi yang dapat diakses dengan mudah mengubah cara manusia memperoleh pengetahuan. Bila pada masa-masa sebelumnya tulisan cetak sangat dominan dalam memuat dan menyampaikan informasi, maka kini gawai telah menjadi platform yang multifungsi. Tidak hanya memperoleh pengetahuan, tetapi juga membagikan pengetahuan dan pengalaman mereka kepada orang lain (Thoman \& Jolls, 2006; Hernelahti \& Kolehmainen, 2014). Kemajuan digitalisasi ini pada akhirnya menimbulkan suatu paradigma dan menambah ruang baru bagi literasi yang dikenal dengan literasi media dan digital (Hobbs \& Coiro, 2016). Teknologi digital yang berkembang telah menjadi bagian yang terintegrasi dengan pendidikan saat ini dan merubah cara peserta didik belajar. Hal tersebut mendorong guru untuk mampu memanfaatkan teknologi informasi dan komunikasi untuk menunjang keterampilan pengembangan media pembelajaran dan pengajaran (Sutrisno, 2011:7). Peserta didik saat ini juga dapat diklasifikasikan sebagai generasi digital asli, yaitu generasi yang lahir dan berkembang diera digital. Sedangkan para guru mayoritas merupakan generasi digital imigran, yaitu generasi yang lahir sebelum era digital. Namun dalam perkembangan usia guru-guru saat ini juga menikmati era digital (Yusnaini \& Slamet, 2019). Sayangnya, menurut Tang \& Chaw (2016) peserta didik kebanyakan menggunakan teknologi tersebut untuk tujuan hiburan dan media sosial, bukan untuk pembelajaran. Maka dari itu, guru memiliki kesempatan baru bagaimana menggunakan teknologi digital untuk membantu para peserta didik belajar secara efektif.

Literasi digital dan TIK (Teknologi Informasi dan Komunikasi) pada perkembangan kehidupan abad 21 telah menjadi suatu keterampilan yang harus dikuasai. Terlebih saat ini angka kepemilikan ponsel pintar di Indonesia menunjukkan bahwa Indonesia telah siap mengadopsi teknologi digital dengan internet, khususnya akses melalui gawai seperti komputer dan ponsel pintar (Rahmah, 2015). Melalui pendidikan, literasi tersebut diberdayagunakan untuk membantu peserta didik membangun pengetahuan dan kecakapan mereka dalam kerangka pendidikan abad 21. Upaya ini sudah dilaksanakan melalui implementasi Kurikulum 2013 yang membuka ruang bagi guru mengembangkan pembelajaran yang dinamis dan fleksibel. Kurniawan (2018:11) menerangkan bahwa pembelajaran menurut Kurikulum 2013 harus mengintegrasikan empat hal penting yakni penguatan pendidikan karakter (PPK), keterampilan literasi, kompetensi abad 21, dan kecakapan berpikir tingkat tinggi dengan harapan peserta didik akan siap bersaing dalam masyarakat global yang kompetitif yang dikemas melalui pembelajaran.

Implementasi Kurikulum 2013 yang telah diuraikan pada paragraf sebelumnya menempatkan pula pembelajaran sejarah sebagai komponen penting dalam praktik pendidikan. Hal tersebut mesti direspons oleh guru sejarah untuk mendesain pembelajaran sejarah abad 21 yang mengintegrasikan pendidikan karakter, keterampilan literasi, kecakapan abad 21, dan berpikir tingkat tinggi. Khususnya melalui kegiatan literasi banyak memberikan manfaat bagi peserta didik yang beberapa diantaranya ialah bertambahnya wawasan, pengetahuan serta informasi baru, meningkatkan kompetensi interpersonal seseorang, mengoptimalkan kinerja dalam kegiatan membaca serta menulism meningkatkan kemampuan verbal, dan meningkatkan kemampuan berpikir dalam menganalisis sesuatu (Fayza, Nugraha, \& Supriyono, 2021). Standar pendidikan yang menuntut kualitas tinggi tersebut hanya dapat dicapai oleh guru dengan kemampuan kreativitas dan tingkat literasi mumpuni. Seperti pada bahasan dalam artikel ini yang menawarkan pembelajaran sejarah lokal dengan memanfaatkan literasi kreatif. Dengan penerapan pendekatan ini dalam pembelajaran sejarah, peserta didik akan dilatih menggunakan berbagai sumber untuk memperoleh informasi dan mengolahnya menjadi produk bermakna. Konsep tersebut akan efektif untuk membantu proses pembelajaran sejarah dan lebih lanjut akan diuraikan pada pembahasan. 


\section{METODE}

Penulisan artikel ini menggunakan studi literatur dengan mengumpulkan berbagai sumber relevan dari buku, jurnal, dan sejumlah hasil penelitian. Dari hasil penghimpunan informasi tersebut, dilakukan analisis dan sintesis untuk membangun deskripsi pembahasan yang bermakna. Penjelasan deskriptif digunakan untuk menggambarkan bagaimana desain pembelajaran sejarah lokal yang kreatif dengan memadukan pendekatan literasi sesuai topik kajian dalam artikel ini. Dengan uraian kata kunci dari konsep-konsep pedagogi kreatif, pembelajaran sejarah lokal, pembelajaran literasi, dan keterampilan abad 21, pembahasan artikel ini dikembangkan untuk menghasilkan konsep literasi kreatif yang dapat diterapkan dalam pembelajaran sejarah dengan menggunakan peristiwa historis dalam kurun waktu Kesultanan Langkat.

\section{PEMBAHASAN}

Pembelajaran Sejarah Kreatif: Pendekatan Literasi dan Multikompetensi Abad 21

Perubahan fundamental banyak dipengaruhi oleh kemajuan ilmu pengetahuan dan kecanggihan teknologi yang mempermudah pekerjaan manusia. Revolusi Industri 4.0 turut mempengaruhi perkembangan pesat ini yang berakibat kepada tuntutan atas sumber daya manusia (SDM) yang kompeten dan memiliki beragam keterampilan atau multikompetensi (Hasan, 2019; Karakoyun \& Lindberg, 2020). Pendidikan sebagai sektor kunci untuk mempersiapkan SDM berkualitas turut bertransformasi diera disruptif ini dengan munculnya konsep pendidikan abad 21. Melalui konsep pendidikan tersebut, dilakukan perbaikan-perbaikan bagaimana menumbuhkembangkan keterampilan yang sesuai dengan kebutuhan zaman dengan memanfaatkan kemajuan teknologi untuk mengkonstruksi pengembangan dan peningkatan pengetahuan, keterampilan, serta sikap pada peserta didik dan juga guru (Boholano, 2017).

Tantangan abad 21 telah memicu dekonstruksi pembelajaran lama yang menekankan aspek transmisi dan ditransformasikan dengan pembelajaran baru yang fokus pada pengembangan berbagai kompetensi. Keterampilan abad 21 tersebut populer dengan istilah 4C yaitu Communication, Collaboration, Critical Thinking and Problem Solving, Creativity and Innovation (Kurniawan, 2020:55). Melalui keterampilan tersebut, seseorang diharapkan dapat menghadapi dan bertahan dengan perubahan yang sangat cepat. Pembelajaran sejarah dalam pembahasan ini beradaptasi dengan mengemukakan pembelajaran sejarah abad 21 yang berbasis kepada kompetensi (Hasan, 2019). Kurikulum 2013 yang berbasis kompetensi telah memberikan kesempatan bagi pembelajaran sejarah untuk mengubah ruang lingkup materi kajian, proses pembelajaran, dan penilaian hasil belajar. Guru sejarah profesional abad 21 dapat merencanakan pembelajaran yang tidak hanya membantu peserta didik memperoleh pengetahuan, tetapi juga menanamkan sikap serta membentuk keterampilan yang dibutuhkan (Susilo \& Sarkowi, 2018). Keterampilan 4C yang disampaikan sebelumnya sangat potensial dikembangkan guru melalui pembelajaran sejarah pada berbagai pokok pembahasan. Tiap materi dalam pembelajaran tersebut dikemas oleh guru sejarah abad 21 dengan berbagai model pembelajaran yang memiliki kesesuaian seperti problem based learning, project based learning, inquiry learning, dan discovery learning (Syaputra \& Sariyatun, 2019).

Pembelajaran literasi dapat dijadikan alternatif pengajaran oleh guru sejarah kreatif. Literasi sangat erat kaitannya dengan pembelajaran sejarah, dimana membaca pasti menjadi aktivitas ketika belajar sejarah. Literasi pada pemahaman lama didefinisikan sebagai melek aksara yang bertumpu pada keterampilan membaca dan menulis. Pada tingkat selanjutnya, literasi dipahami sebagai kemampuan membaca, menulis, berbicara, dan menyimak (Abidin, 2018:49). Akan tetapi pada kehidupan abad 21 ini, literasi dimaknai lebih luas lagi dengan berbagai istilah seperti literasi informasi, literasi digital, literasi keuangan, literasi kesehatan, literasi visual, literasi teknologi dan sebagainya 
yang disebut dengan literasi baru (Kurniawan, 2018: 99; Abidin, 2018:50-51). Mencermati pengertian mengenai literasi, maka pembudayaan literasi yang baik akan menumbuhkan generasi yang mahir membaca, menulis, memahami teks bahkan menyampaikan gagasan dengan baik pula. Kesempatan tersebut sangat potensial dioptimalkan melalui pembelajaran sejarah kreatif. Dalam pembelajaran sejarah, literasi informasi bisa diperoleh dari berbagai sumber seperti buku, dokumen, arsip, surat kabar, bahkan artefak seperti bangunan bersejarah (Mulyati \& Tarusena, 2017). Ketersediaan sumber belajar sejarah yang melimpah tersebut didukung pula oleh kemudahan akses yang secara langsung juga melatih literasi digital dan teknologi.

Pembelajaran literasi dalam sejarah yang kaya peluang tersebut dihadapkan pada tantangan mengenai strategi dan model pembelajarannya. Guru sejarah kreatif akan cermat merespons tantangan tersebut dengan menghubungkan pembelajaran sejarah berbasis literasi dengan pembelajaran abad 21. Guru sejarah kreatif bisa menerapkan model pembelajaran yang meningkatkan kreativitas seperti inquiry, discovery, ataupun simulasi (Hosnan, 2014:351). Guru sejarah kreatif dapat mengangkat sejarah lokal dengan menerapkan model pemecahan masalah dan pendekatan penelitian sejarah. Peserta didik akan mengidentifikasi permasalahan yang ditawarkan oleh guru dan menyusun pemecahan masalah melalui proses pengumpulan informasi (heuristik) melalui kegiatan literasi. Dari proses heuristik tersebut, mereka telah dilatih berliterasi dengan mencari informasi relevan dan mengidentifikasi kesesuaiannya dengan kajian mereka. Kemudian, mereka melakukan analisis yang melatih kemampuan berpikir kritis dan menyusun hasil penelusuran itu dalam bentuk tulisan kreatif (historiografi). Tulisan kreatif tersebut dapat berupa laporan terstruktur, narasi berbentuk prosa, peta informatif, video, ataupun produk kreatif lain yang dapat dikomunikasikan kepada peserta didik lainnya (Garvey \& Krug, 2015). Dari rangkaian proses pembelajaran tersebut peserta didik telah dilatih mendayagunakan literasi untuk pemecahan masalah, berpikir kritis, komunikatif, dan kreatif. Bahkan, guru dapat membantu keterampilan kerjasama (kolaborasi) dan kepemimpinan peserta didik dengan memadukan model cooperative learning (Daryanto \& Karim, 2017:134).

Integrasi berbagai pendekatan tersebut telah memunculkan literasi kreatif yang menggunakan beragam sumber informasi yang dikemas sedemikian rupa untuk memecahkan persoalan dan hasilnya disampaikan secara kreatif (Gregori-Signes, 2014; Hernelahti \& Kolehmainen, 2014). Literasi kreatif yang diterapkan tersebut menjadi contoh dari pengembangan pedagogi kreatif. Unsur-unsur pedagogi kreatif pun tercapai melalui literasi kreatif tersebut yang antara lain terdiri dari creative teaching, teaching for creativity, dan creative learning. Pedagogi kreatif sendiri menurut penjelasan Supriatna \& Maulidah (2020) ialah perencanaan, pelaksanaan kegiatan dan proses belajar mengajar yang imajinatif dan inovatif dalam kurikulum dan dalam strategi pembelajaran di ruang kelas untuk pengembangan kreativitas peserta didik. Kreativitas menjadi kata kunci dalam pedagogi kreatif yang merupakan salah satu keterampilan abad 21 yang hendak dicapai (Hasan, 2019). Guru kreatif akan memanfaatkan apapun yang ada dilingkungannya sebagai sumber belajar baik peristiwa sejarah lokal, kebudayaan lokal, ataupun fenomena sosial yang ada disekitar peserta didik. Pembelajaran kreatif yang memberikan kewenangan kepada peserta didik akan memberikan ruang bagi mereka mengajukan pertanyaan, mencari, memanipulasi, bereksperimen, dan mengeksplorasi rasa ingin tahunya (Lin, 2011). Dalam pembelajaran kreatif tersebut, peserta didik menjadi subjek yang memiliki peluang bersosialisasi, bekerjasama, dan mengembangkan imajinasi dan berpikir dengan cara mereka sendiri (Supriatna \& Maulidah, 2020; Selkrig \& Keamy, 2017). Seluruh elemen tersebut dielaborasikan guru sejarah kreatif dengan pendekatan literasi, sehingga melahirkan pembelajaran literasi kreatif yang sekaligus 
membantu peserta didik menumbuhkan keterampilan abad 21 pada diri mereka.

\section{Sejarah Kesultanan Langkat: Potensi bagi Pembelajaran Sejarah Kreatif}

Narasi dalam kurikulum pelajaran sejarah di Indonesia sudah pasti memuat konten sejarah nasional yang terkadang jauh dari pengalaman ataupun lingkungan hidup peserta didik sebagai pembelajar sejarah. Maka, fleksibilitas menjadi prinsip penting dalam pengembangan kurikulum yang dilakukan guru sejarah untuk merencanakan pembelajaran (Sukmadinata, 2019). Berkaitan dengan pedagogi kreatif dalam pembelajaran sejarah, guru dapat mengangkat isu-isu setempat seperti sejarah lokal. Posisi sejarah lokal bila dioptimalkan dapat menjadi objek studi sejarah peserta didik yang memberi kesempatan mereka belajar mengembangkan wawasan, pemahaman, dan keterampilan penelitian sejarah (Hasan, 2012; Wiyanarti, Supriatna, \& Winarti, 2020). Keterampilan penelitian sejarah merupakan kemampuan untuk meneliti suatu peristiwa sejarah yang dilaksanakan dalam lingkup lokal yang dapat berupa tempat tinggal, sekitar lingkungan sekolah atau kawasan tertentu yang diminati. Dengan arahan guru, peserta didik difasilitasi melalui pembelajaran untuk mengkonstruksi pengetahuan mengenai lingkungan terdekatnya sekaligus membentuk karakter dan keterampilan pada dirinya. Karakter dasar yang dapat ditumbuhkan dari pembelajaran sejarah lokal ini antara lain dikemukakan oleh Permana (2020) seperti religius, tanggung jawab, disiplin, mandiri, jujur, peduli sekitar, kerjasama, kepemimpinan, toleransi, dan persatuan.

Pembelajaran sejarah lokal sebagai pengayaan dalam pembelajaran sejarah sangat potensial bila dikorelasikan dengan pendekatan pedagogi kreatif. Dalam pembahasan ini, Penulis mencoba mengangkat sejarah lokal dikawasan Sumatera Utara yaitu Kesultanan Melayu Langkat sebagai alternatif pembelajaran sejarah yang dikemas dalam kerangka pembelajaran literasi yang berlandaskan pedagogi kreatif. Kesultanan Langkat berkembang sejak tahun $1500 \mathrm{M}$ dari negeri kecil hingga menjadi kerajaan kaya yang runtuh pada penghujung tahun 1946 akibat revolusi sosial (Husin, 2015; Sinar, 2002; Arifin, 2009). Dari perkembangan sejarah kerajaan Melayu ini, ada beragam topik yang dapat diangkat oleh guru sejarah dan peserta didik untuk merancang pembelajaran sejarah lokal yang kreatif. Beberapa contoh yang dapat dijadikan topik pembahasan dari sejarah lokal Kesultanan Langkat dapat ditarik dari periodesasi atau pembahasan pada sejarah nasional. Misalnya pada masa Islam di Indonesia dapat diperkaya dengan pendidikan Islam di Langkat dengan adanya lembaga pendidikan Madrasah Jam'iyah Mahmudiyah yang hingga saat ini masih beroperasi (Ramadhan, 2019). Pada materi kolonialisme beberapa topik yang dapat diangkat ialah perkebunan tembakau, produksi lada, pertambangan minyak komersial pertama di Indonesia, dan juga jaringan kereta api. Tragedi revolusi sosial, peristiwa Brandan Bumi Hangus 1947 yang serupa dengan Bandung Lautan Api, serta pahlawan nasional Tengku Amir Hamzah dapat pula dijadikan pembahasan pada topik mempertahankan kemerdekaan. Migrasi penghijrah dari Semenanjung Malaya pada era kolonial yang saat ini telah berbaur menjadi warga negara Indonesia, bahkan dapat dijadikan materi pembelajaran dengan pendekatan multikulturalisme (Tanjung \& Sinaga, 2019). Semua topik yang diuraikan tersebut sangatlah terbuka dan memiliki keterkaitan bila dihubungkan dengan sejarah nasional dan menghadirkan bahwa sejarah itu dekat dengan peserta didik.

Langkah pertama yang diambil oleh guru untuk merencanakan pembelajaran ialah menentukan topik apa yang akan dipelajari. Fase ini sangat memungkinkan keterlibatan peserta didik dalam menentukan hal apa yang akan dikaji oleh mereka dengan tetap mempertimbangkan kompetensi dari kurikulum yang diterapkan. Aspek ini mengindikasikan guru yang demokratis dan memenuhi ciri dari guru sejarah abad 21 (Fatmawati \& Setiawati, 2018). Kemudian, guru dapat merencanakan strategi apa yang akan digunakan seperti pendekatan saintifik, model pembelajaran, tujuan pembelajaran, kompetensi yang hendak 
dibangun, sumber yang akan digunakan, serta cara asesmen (Daryanto \& Dwicahyono, 2014). Pembentukan sikap dan keterampilan tetap terintegrasi melalui proses pembelajaran bersamaan dengan upaya membangun pengetahuan peserta didik. Pembelajaran sejarah abad 21 dapat mengacu pada tiga prinsip pedagogis yang diuraikan oleh McLoughlin \& Lee (Supriatna \& Maulidah, 2020) yaitu personal (guru dan peserta didik memiliki karakteristik tersendiri), partisipatif (melibatkan peserta didik aktif dalam pembelajaran), dan produktif (memfasilitasi peserta didik mengembangkan keterampilan yang produktif). Melaksanakan pembelajaran yang telah dirancang tersebut dapat dikembangkan lagi oleh guru dengan menggunakan pendekatan literasi. Pembelajaran yang berbasis pada literasi secara langsung melatih pula peserta didik untuk memperoleh dan mengolah informasi. Informasi tersebut dikumpulkan oleh mereka melalui banyak sumber baik cetak maupun digital. Dengan menerapkan model cooperative-discovery learning, peserta didik dapat membangun pengetahuannya melalui rangkaian kegiatan pembelajaran yang menekankan pada proses berpikir kritis dan analitis untuk mencari dan menemukan jawaban secara berkelompok dari suatu permasalahan (Kurniawan, 2018). Melalui model tersebut, Abidin (2018) menyampaikan bahwa guru dan peserta didik dapat menerapkan sintaks model multiliterasi informasi dengan langkah-langkah prosedural (1) menetapkan masalah; (2) membuat pertanyaan pemandu dengan bimbingan guru; (3) menemukan sumber informasi; (4) mencatat informasi seperti mengutip, merangkum, atau membuat parafrase; (5) menyeleksi informasi; (7) mengolah informasi seperti membuat inferensi, membuat sintesis, dan mengevaluasi isi bacaan; (8) menyimpulkan informasi; dan (9) memproduksi karya. Cara tersebut tidak menutup kemungkinan untuk disederhanakan guru dengan metode sejarah yang terdiri dari menentukan topik, mengumpulkan sumber, kritik sumber, penafsiran, serta penjelasan dan penyajian (Sjamsuddin, 2016).
Pembelajaran sejarah lokal berbasis literasi yang menerapkan kolaborasi model cooperativediscovery learning dan sintaks model multiliterasi informasi akan membina kemampuan peserta didik dalam menemukan, mencatat, menganalisis, mengkritisi, dan membuat perspektif baru dari sebuah informasi (Abidin, 2018). Dalam praktiknya, peserta didik ditugaskan menemukan sebanyak mungkin informasi dari berbagai sumber baik tekstual maupun digital. Untuk efisiensi, guru dan peserta didik dapat menggunakan gawai untuk memperoleh informasi dari internet dan ini sangat baik untuk meningkatkan literasi digital peserta didik (Risinger, 2010). Guru dapat mendorong peserta didik untuk mengoptimalkan gawai mereka dengan mengakses informasi melalui blog, e-book, e-library atau hasil penelitian seperti jurnal dan skripsi pada repositori perguruan tinggi. Cara mengumpulkan informasi ini sudah menunjukkan kreativitas peserta didik yang selanjutnya mereka akan menyeleksi informasi yang dibutuhkan dan relevan untuk diolah. Dalam pengolahan informasi ini, mereka akan membangun kesimpulan dan hasilnya dikemas melalui produk kreatif yang dapat mengembangkan imajinasi dan menunjukkan pula minat serta bakat mereka.

Penilaian tidak dapat diabaikan pula sebagai instrumen desain pembelajaran yang harus disusun berdasarkan tujuan dalam pembelajaran. Dalam pembelajaran sejarah lokal berbasis literasi ini, aspek yang dinilai harus bersesuaian dengan kompetensi yang diarahkan kurikulum yakni sikap, pengetahuan, dan keterampilan. Guru dapat mengembangkan suatu instrumen untuk menilai ketiga aspek tersebut menggunakan penilaian autentik yang memungkinkan penilaian telah dijalankan sejak proses belajar berlangsung hingga selesai (Irwantoro \& Suryana, 2016). Guru bahkan dapat memadukan beberapa bentuk dari penilaian autentik yang disesuaikan dengan kondisi pembelajaran seperti penilaian kinerja, penilaian sebaya, penilaian produk ataupun penilaian tertulis.

Keterampilan yang dilatih melalui pembelajaran cooperative-discovery learning tersebut 
akan membentuk kemahiran dalam diri peserta didik seperti bekerjasama (kolaborasi), menyatukan gagasan, mengidentifikasi masalah, berpikir kritis, memecahkan masalah, mengoptimalkan potensi kreatif mereka, dan melatih kepercayaan diri dari keterampilan komunikasi. Hal tersebut telah membentuk multikompetensi yang sangat dibutuhkan dikehidupan abad 21 ini. Bahkan, melalui sintaks model multiliterasi informasi telah memberikan pemahaman kepada peserta didik untuk menerapkan kegunaan gawai dan kemudahan digital untuk memperoleh informasi dan mengkritisinya untuk diolah lebih lanjut. Proses tersebut telah mengupayakan pemahaman literasi bagi peserta didik dan membekali mereka dengan multikompetensi melalui pembelajaran sejarah lokal yang dirangkai dengan pemanfaatan literasi dan pendekatan pedagogi kreatif. Selain itu, karakteristik peserta didik yang nasionalis diperoleh pula melalui pembelajaran sejarah dengan memaknai beragam peristiwa dan menggali nilai-nilai yang terkandung untuk diinternalisasikan serta diamalkan dalam kehidupan bermasyarakat.

\section{SIMPULAN}

Isu-isu sejarah lokal sangatlah potensial untuk diangkat menjadi pembelajaran kreatif yang mendukung keberhasilan belajar peserta didik. Gambaran itu ditunjukkan melalui peluang penerapan pembelajaran sejarah lokal Kesultanan Langkat yang dapat dikemas dengan pendekatan pedagogi kreatif. Dalam pedagogi kreatif, kedudukan guru dan peserta didik adalah sebagai mitra dengan karakteristik tersendiri. Peserta didik didorong pula untuk partisipatif dan produktif melalui pembelajaran sesuai prinsip pembelajaran abad 21. Untuk memperoleh pengetahuan, pengembangan sikap, dan keterampilan yang sesuai dengan tuntutan kebutuhan saat ini, pembelajaran dapat menggunakan literasi sebagai basis dalam pelaksanaan pembelajaran. Integrasi berbagai pendekatan tersebut didukung dengan menggunakan model pembelajaran yang sesuai kondisi peserta didik dan tujuan pembelajaran. Sehingga dari proses pembelajaran tersebut, peserta didik dilatih dengan berbagai keterampilan seperti kemampuan literasi, berpikir kritis, pemecahan masalah, kerjasama, keterampilan komunikasi, kepemimpinan, kreatif, dan produktif. Literasi kreatif menjadi alternatif dalam pembelajaran sejarah abad 21 , dimana literasi memiliki peran penting untuk membantu peserta didik mengkonstruksi pengetahuan dan keterampilannya. Kajian ini sangat menarik bagi Penulis untuk dikembangkan lebih lanjut dalam kerangka riset ilmiah untuk memperoleh hasil yang akurat dan kredibel.

\section{DAFTAR PUSTAKA}

Abidin, Y. (2018). Pembelajaran Multiliterasi: Sebuah Jawaban atas Tantangan Pendidikan Abad Ke21 dalam Konteks Keindonesiaan. Bandung: Refika Aditama.

Arifin, Zainal. (2009). Langkat dalam Sejarah dan Perjuangan Kemerdekaan. Medan: Mitra.

Boholano, H.B. (2017). Smart Social Networking: $21^{\text {st }}$ Century Teaching and Learning Skills. Research in Pedagogy, 7(1), 21-29. doi: 10.17810/2015.45

Daryanto \& Karim, S. (2017). Pembelajaran Abad 21. Yogyakarta: Gava Media.

Daryanto, \& Dwicahyono, A. (2014). Pengembangan Perangkat Pembelajaran (Silabus, RPP, PHB, Bahan Ajar). Yogyakarta: Gava Media.

Fatmawati \& Setiawati, D. (2018). Pengembangan Kompetensi Guru Sejarah dalam menghadapi Tantangan Abad 21. Jurnal Mitra Pendidikan (JMP Online), 2(11), 1259-1270.

Fayza, A.A., Nugraha, D.M., \& Supriyono. (2021). Pengaruh Literasi terhadap perkembangan Pembelajaran PKN. Jurnal Harmony, 6(1), 5765.

Garvey, B., \& Krug, M. (2015). Model-model Pembelajaran Sejarah di Sekolah Menengah. Yogyakarta: Ombak

Gregori-Signes, C. (2014). Digital Storytelling and Multimodal Literacy in Education. Porta linguarum, (22), 237-250.

Hasan, S.H. (2012). Pendidikan Sejarah Indonesia: Isu dalam Ide dan Pembelajaran. Bandung: Rizqi Press 
Hasan, S.H. (2019). Pendidikan Sejarah untuk Kehidupan Abad ke 21. Historia: Jurnal Pendidik dan Peneliti Sejarah, 2(2), 61-72.

Hernelahti, S. \& Kolehmainen, S. 2014. Creative Literacy as a way for Multiliteracy. IFLA 2014 Lyon, https://creativecommons.org/license/bv/3.0/

Hobbs, R. \& Coiro, J. 2016. Everyone Learns from Everyone: Collaborative and Interdisciplinary Professional Development in Digital Literacy. Journal of Adolescent \& Adult Literacy 59(6).

Hosnan. (2014). Pendekatan Saintifik dan Kontekstual dalam Pembelajaran Abad 21: Kunci Sukses Implementasi Kurikulum 2013. Bogor: Ghalia Indonesia

Husin, D.A. (2015). Sejarah Kesultanan Langkat. Tanpa Penerbit.

Irwantoro, N. \& Suryana, Y. (2016). Kompetensi Pedagogik: untuk Peningkatan dan Penilaian Kinerja Guru dalam Rangka Implementasi Kurikulum Nasional. Surabaya: Genta Group.

Karakoyun, F., \& Lindberg, O.J. (2020). Preservice Teachers' Views about the Twenty-first Century Skills: A Qualitative Survey Study in Turkey and Sweden. Educatioan and Information Technologies, 25, 2353-2369. doi: 10.1007/s10639-020-10148-w

Kurniawan, H. (2018). Literasi dalam Pembelajaran Sejarah. Yogyakarta: Gava Media

Kurniawan, H. (2020). Pembelajaran Era 4.0: Integrasi Penguatan Pendidikan Karakter, Keterampilan Abad 21, HOTS, dan Literasi dalam Perspektif Merdeka Belajar. Yogyakarta: Media Akademi.

Lin, Y.S (2011). Fostering Creativity through Education: a Conceptual Framework of Creative Pedagogy. Journal Creative Education, 2(3).

Mulyati, E. \& Tarunasena. (2017). Penggunaan Metode In the News untuk meningkatkan Kemampuan Literasi Informasi Siswa dalam Pembelajaran Sejarah (Penelitian Tindakan kelas di Kelas XI MIA 2 SMA Kartika XIX-1 Bandung). Factum, 6(1), hlm 43-61.

Permana, R. (2020). Pembelajaran Sejarah Lokal di Sekolah. Tangerang: Media Edukasi Indonesia
Rahmah, A. (2015). Digital Literacy Learning System for Indonesian Citizen. Procedia Computer Science, 72, 94-101.

Ramadhan, S. (2019). Madrasah Jam'iyah Mahmudiyah: Sejarah Pendidikan Islam di Langkat tahun 1921-1950. Jurnal Jasmerah, 1(2), 74-84.

Risinger, C.F. (2010). Learning and Writing about Local Hisroty Using the Internet. Social Studies, 74(2), $76-81$.

Selkrig, M. \& Keamy, K. (2017). Creative Pedagogy: A Case for Teachers' Creative Learning being at the Centre. Journal Teaching Education. doi: $10.1080 / 10476210.2017 .129682$

Sinar, T.L. 2002. Bangun dan Runtuhnya Kerajaan Melayu di Sumatera Timur. Tanpa Penerbit.

Sjamsuddin, H. (2016). Metodologi Sejarah. Yogyakarta: Ombak

Sukmadinata, N.S. (2019). Pengembangan Kurikulum: Teori dan Praktik. Bandung: Rosda.

Supriatna, N., \& Maulidah, N. (2020). Pedagogi Kreatif: Menumbuhkan Kreativitas dalam Pembelajaran Sejarah dan IPS. Bandung: Rosda.

Susilo, A., \& Sarkowi. (2018). Peran Guru Sejarah Abad 21 dalam menghadapi Tantangan Arus Globalisasi. Historia: Jurnal Pendidik dan Peneliti Sejarah, 2(1), 43-50.

Sutrisno. (2011). Pengantar Pembelajaran Inovatif berbasis Teknologi Informasi dan Komunikasi. Jakarta: Gaung Persada Press.

Syaputra, E., \& Sariyatun. (2019). Pembelajaran Sejarah di Abad 21 (Telaah Teoritis terhadap Model dan Materi). Yupa: Historical Studies Journal, 3(1), 18-27.

Tang, C.M., \& Chaw, L.Y. (2016). Digital Literacy: A Prerequisite for Effective Learning in a Blended Learning Environment. The Electronic Journal of e-Learning, 14,54-65.

Tanjung, S., \& Sinaga, R. (2019). Masyarakat Sungai Babalan: Sejarah Sosial Desa Perlis, Pangkalan Brandan (1940-2004). Jurnal Jasmerah, 1(1), 113.

Thoman, E. \& Jolls, T. (2003). Literacy for the $21^{\text {st }}$ Century: An Overview \& Orientation Guide to 
Media Literacy Education. Access on Yusnaini \& Slamet. (2019). Era Revolusi Industri 4.0: www.medialit.org

Wiyanarti, E., Supriatna, N., \& Winarti, M. (2020). Pengembangan Sejarah Lokal sebagai Sumber Pembelajaran Sejarah yang Kontekstual. Tantangan dan Peluang dalam upaya meningkatkan Literasi Pendidikan. Prosiding Seminar Nasional Pendidikan Program Pascasarjana Universitas PGRI Palembang. Factum: Jurnal Sejarah dan Pendidikan Sejarah, $9(1)$. 